\title{
Prostatic urethral cyst: a rare cause of acute urinary retention in a young male
}

\author{
Murali Krishna, Kalpesh Mahesh Parmar 두, Yashaswi Thummala, Santosh Kumar
}

Department of Urology, Post Graduate Institute of Medical Education and Research, Chandigarh, India

\section{Correspondence to} Dr Kalpesh Mahesh Parmar; kalpesh010385@gmail.com

Accepted 26 February 2021

\section{DESCRIPTION}

A 31-year-old male medical professional presented with acute urinary retention. He had frequency, straining and sense of incomplete emptying of 3-day duration. There was no history of dysuria, fever or urethral instrumentation. He is unmarried and sexually inactive. On examination, he was conscious and his vitals were stable. Systemic examination showed palpable urinary bladder up to umbilicus suggestive of urinary bladder outlet obstruction. Ultrasonography of the abdomen showed cystic structure $2 \times 2 \mathrm{~cm}$ at the bladder neck and bilateral kidneys were normal. A 14-Fr Foley catheter was placed for relief of urinary retention, which recorded $630 \mathrm{~mL}$ of residual urine. Routine work-up, including haemogram, renal function and urine analysis, was normal. A contrast-enhanced CT of the abdomen with urography showed a well-defined cystic lesion arising from prostatic urethra and projecting into urinary bladder lumen suggestive of prostatic cyst (figure 1A,B). Rest of the urinary bladder, prostate and kidneys was normal. He was counselled about the various possible differential diagnoses and treatment options, including needle aspiration and transurethral resection. Patient chose to undergo transurethral resection of cyst, which was done under regional anaesthesia. Intraoperatively, urinary bladder showed mild trabeculations and $1 \times 2 \mathrm{~cm}$ thick walled cyst was seen extending from 6 o'clock to 10 o'clock position at bladder neck causing narrowing of the lumen (figure 2A,B). Clear fluid was aspirated endoscopically. Using 26-Fr resectoscope, complete resection of prostatic cyst was done and 22-Fr three-way Foley's catheter was placed with continuous bladder irrigation (figure 2C,D). Postoperative period was uneventful. Histopathological examination showed cyst wall lined by transitional epithelium

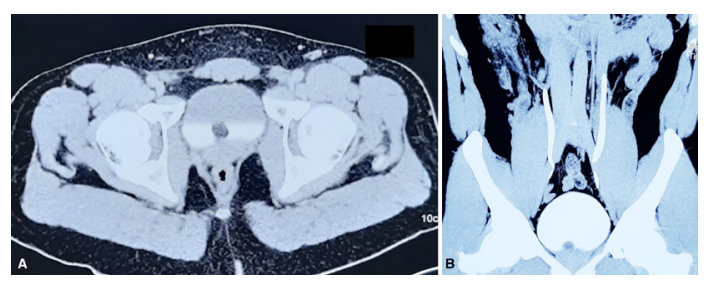

Figure 1 Contrast-enhanced $\mathrm{CT}$ of the abdomen with urography images. (A) Axial image showing cystic lesion at the level of urinary bladder neck projecting into the lumen. (B) Coronal image showing cystic lesion arising from prostatic urethra with bilateral normal excretory kidneys.

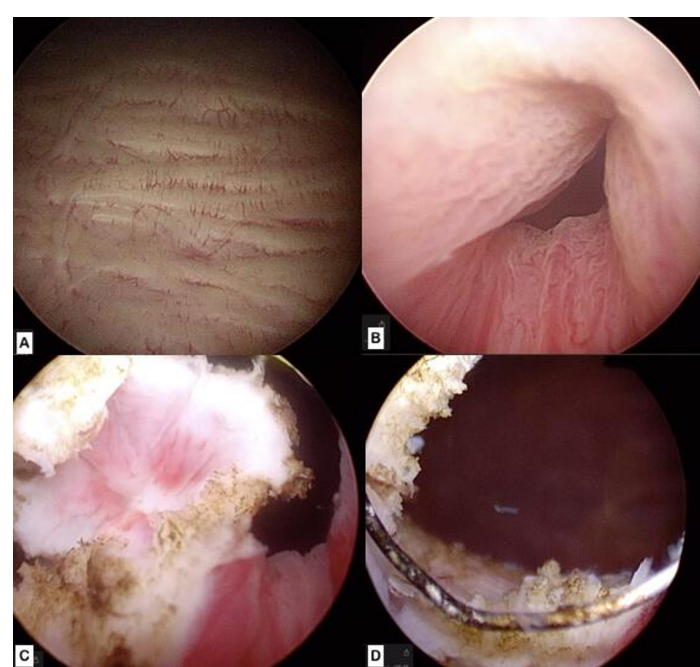

Figure 2 Intraoperative images showing (A) trabeculated urinary bladder suggestive of bladder outlet obstruction, (B) epithelial lined cystic lesion in prostatic urethra at the level of urinary bladder neck extending from 6 o'clock to 10 o'clock position, (C) resection of cyst and (D) raw area with widely opened urinary bladder neck after cyst resection.

of prostatic urethra comprised of fibrocollagenous tissue and smooth muscle fibres. At 3-month follow-up, he is asymptomatic and doing well. Prostatic cyst has an incidence of around 5\% in the referral population and around $1 \%$ of these cases have a symptomatic presentation. ${ }^{1}$ Common symptoms associated with prostatic cysts include dysuria, haematuria, haematospermia, infertility and recurrent urinary tract infection. Acute urinary retention is an uncommon presentation for prostatic cysts. Imaging such as ultrasound, CT or MRI could assist in the diagnosis. Common differential diagnosis includes Mullerian duct cysts, bladder diverticulum, seminal vesicle cyst and Wolffian duct cyst. ${ }^{2}$ Furuya et al classified prostatic cyst on imaging based on its communication with urethra and seminal vesicles. ${ }^{3}$ Symptomatic prostatic cysts require active intervention. Ultrasound-guided aspiration or endoscopic marsupialisation, transrectal ultrasound-guided aspiration and excision of cyst are the current treatment modalities being used. Lee et $a l^{4}$ and Chang et $a l^{5}$ have reported transurethral resection of prostatic cyst aids in complete removal of cyst and resolution of symptoms with no long-term complications. Though it is rare, prostatic cysts should be kept as a differential diagnosis in a young male presenting with urinary retention. 


\section{Patient's perspective}

I am pleased with treatment and proper guidance by the whole team of doctors.

\section{Learning points}

- Prostatic urethral cyst is a rare cause of acute urinary retention.

- Transurethral complete resection of cyst is the preferred surgical choice with possibly less chance of recurrence.

Contributors MK and KMP: collected data, images and initial draft of the manuscript. YT: manuscript editing. SK: critical comments.

Funding The authors have not declared a specific grant for this research from any funding agency in the public, commercial or not-for-profit sectors,
Competing interests None declared.

Patient consent for publication Obtained.

Provenance and peer review Not commissioned; externally peer reviewed.

\section{ORCID iD}

Kalpesh Mahesh Parmar http://orcid.org/0000-0003-3891-4089

\section{REFERENCES}

1 Ishikawa M, Okabe H, Oya T, et al. Midline prostatic cysts in healthy men: incidence and transabdominal sonographic findings. AJR Am J Roentgenol 2003;181:1669-72.

2 Qiu Y, Liu Y, Ren W, et al. Prostatic cyst in general practice: a case report and literature review. Medicine 2018;97:e9985.

3 Furuya R, Furuya S, Kato H, et al. New classification of midline cysts of the prostate in adults via a transrectal ultrasonography-guided opacification and dye-injection study. BJU Int 2008;102:475-8.

4 Lee J-Y, Kang D-H, Park H-Y, et al. An anteriorly positioned midline prostatic cyst resulting in lower urinary tract symptoms. Int Neurourol J 2010;14:125-9.

5 Chang S-G, Hwang I-C, Lee J-H, et al. Infravesical obstruction due to benign intraurethral prostatic cyst. J Korean Med Sci 2003;18:125-6.

Copyright 2021 BMJ Publishing Group. All rights reserved. For permission to reuse any of this content visit

https://www.bmj.com/company/products-services/rights-and-licensing/permissions/

BMJ Case Report Fellows may re-use this article for personal use and teaching without any further permission.

Become a Fellow of BMJ Case Reports today and you can:

- Submit as many cases as you like

- Enjoy fast sympathetic peer review and rapid publication of accepted articles

- Access all the published articles

- Re-use any of the published material for personal use and teaching without further permission

Customer Service

If you have any further queries about your subscription, please contact our customer services team on +44 (0) 2071111105 or via email at support@bmj.com.

Visit casereports.bmj.com for more articles like this and to become a Fellow 